\title{
Immune response in shipyard workers with $x$ ray abnormalities consistent with asbestos exposure
}

\author{
H ANTON-CULVER, B D CULVER, T KUROSAKI \\ From the Department of Community and Environmental Medicine, University of California, Irvine, \\ California 92717, USA
}

ABSTRACT The association of cellular and humoral immune responses with asbestos exposure was studied in two groups of 150 workers each from a shipyard population and compared with a population of Red Cross blood donors. One of the shipyard groups had both chest $x$ ray evidence of asbestos exposure and work assignments that necessitated direct handling of asbestos. The other shipyard group had normal chest $x$ ray films and no job assignments involving the direct handling of asbestos. Cellular immune responses studied were mitogen activation and measures of $T$ helper and $T$ suppressor cells. Humoral immune measures were $\operatorname{IgG}, \operatorname{IgA}$, and $\operatorname{IgM}$. In shipyard workers with asbestos related $x$ ray abnormalities there was a significant increase in pokeweed mitogen stimulation. In both shipyard groups compared with Red Cross blood donors were found (1) significantly higher IgG and IgA levels and (2) greater numbers of Thelper and T suppressor cells; because of the disproportionately large number of $\mathrm{T}$ suppressor cells, $\mathrm{Th} / \mathrm{Ts}$ ratios were lower than in the Red Cross controls. Observations of differences in humoral and cellular immune response may point the way to the early diagnosis of the clinical manifestation of asbestos related disease.

Both malignant and non-malignant diseases have been found to occur at a higher rate than expected in subjects exposed to asbestos. ${ }^{1-7}$ These diseases include lung cancer, gastrointestinal cancer, mesothelioma, and fibrosis of the lung. Both malignant neoplasms and non-malignant lung disease have been associated with an impaired immunological response in the host. ${ }^{8-10}$ The host immunological response to asbestos exposure has been studied in both animal and man..$^{8-16}$

An immune response in the form of immune stimulation or suppression should be considered an abnormal reaction and if it occurs in association with exposure to substances such as asbestos the question should be asked whether the response is predisposing to the clinical manifestation of disease. Thus we have measured immune response as a possible index of the toxic effect of asbestos exposure in the hope that such response may serve as a clue to the early detection of subjects at risk for developing asbestos related disease. It seems likely from studies using the animal model and human populations exposed to asbestos that exposure may modify immune responses before the appearance of any pathological lesion. ${ }^{11-15}$

Our report is based on the study of several immunological markers tested in a well defined group of

Accepted 17 July 1987 shipyard workers exposed to asbestos and having chest $x$ ray abnormalities consistent with exposure to asbestos including pleural plaques. The following hypotheses are tested:

(1) Subjects with chest $x$ ray abnormalities consistent with asbestos exposure have altered levels of circulating immunoglobulins and their peripheral blood lymphocytes have an altered ability to respond in vitro to plant mitogens (pokeweed and phytohaemagglutinin) when compared with controls.

(2) Of subjects exposed to asbestos, those with an identified tissue response, predominately pleural plaque, have altered levels of circulating immunoglobulins and their peripheral blood lymphocytes have an altered ability to respond in vitro to plant mitogens (pokeweed and phytohaemagglutinin) when compared with controls.

\section{Methods}

\section{SUBJECTS UNDER STUDY}

Three groups were studied.

The experimental group consisted of 150 subjects of a West Coast shipyard randomly selected from those who were diagnosed as having chest $x$ ray abnormalities consistent with asbestos exposure. These abnormalities were pleural plaques, present in all 
members of the experimental group; a few members of this group also had pleural thickening and parenchymal fibrosis.

A control group consisted of 150 shipyard workers who had no chest $x$ ray abnormalities but who worked in the same shipyard as the experimental group and matched the experimental group for age within five years. The control subjects had no job assignment at the shipyard necessitating direct handling of asbestos; however, some had incidental exposure to asbestos. It should be emphasised that the subjects in the control group were selected for the absence of chest $x$ ray abnormalities rather than having been selected for the absence of asbestos exposure. The purpose of the study is to look for immune differences associated with the biological response of asbestos exposure.

A second control group consisted of 634 male Red Cross blood donors from Southern California. The age range in this group was similar to that of the shipyard worker groups. Blood samples were obtained at the same time and processed in the same laboratory as the samples from the shipyard groups.

\section{DATA COLLECTION}

Data were collected during interviews of each shipyard worker to obtain information about jobs necessitating exposure to asbestos held before joining the shipyard. Dates of employment were collected for each worker as were data about other exposures to chemicals. Additional questionnaire data included demographic information, habit patterns such as smoking and drinking, and medical history. An asbestos exposure index (AEI) was calculated using the following equation: $\mathrm{AEI}=3 \mathrm{~A}+2 \mathrm{~B}+\mathrm{C}$, where $\mathrm{A}=$ duration of employment in high intensity exposure shops, $\mathrm{B}=$ duration of employment in intermediate exposure shops, and $\mathrm{C}=$ duration of employment in low intensity exposure shops. Descriptive data on the shipyard groups are shown in table 1.

\section{LABORATORY METHODS}

Specimen preparation

Blood samples were collected from each worker on Mondays at 0700 before breakfast and then transferred for processing to the central laboratory. Serum samples were separated from clot within three to five hours of collection and frozen at $-70^{\circ} \mathrm{C}$. A heparinised blood sample was used to perform a white blood cell count (WBC), differential count, and T cell subset analysis. These measurements were also made within three to five hours. An additional sample of heparinised blood was drawn for Ficoll-Hypaque separation to permit analysis of lymphocyte subsets by dual fluorescence and to permit mitogen activation assays.

\section{Lymphocyte subset determinations}

Total lymphocyte count-Total lymphocyte count was determined from a white blood cell count using a Coulter counter and a differential count on 100 cells.

Immunofluorescent measurement of lymphocyte subsets - Levels of T cells, T helper (Th) cells, and T suppressor (Ts) cells were determined using the monoclonal antibodies listed below.

$\begin{array}{ll}\text { Antibody } & \text { Reactive cell } \\ \text { OKT3 } & \text { Total T cells } \\ \text { OKT4 } & \text { T helper/inducer cells } \\ \text { OKT4A } & \text { T helper/inducer cells } \\ \text { OKT8 } & \text { T suppressor/cytotoxic cells }\end{array}$

Both indirect and direct immunofluorescence were routinely performed. Indirect immunofluorescence uses a monoclonal antibody as the primary antibody and a FITC conjugated goat antimouse immunoglobulin antibody as the secondary antibody. Background immunofluorescence was determined using murine gamma-2a myeloma protein as primary antibody. Direct immunofluorescence used FITC conjugated monoclonal antibody. Whole blood collected in EDTA vacutainer tubes was treated with monoclonal antibodies and fluorescinated cells were analysed using an automated flow cytometer (Spectrum III Ortho Diagnostics). Lymphocyte populations were distinguished from monocytes and granulocytes by correlated analysis of forward and right angle scatter. The percentage of cells positive for immunofluorescence was used in conjunction with the absolute lymphocyte count to determine the absolute number of cells bearing a given marker and the $\mathrm{Th} / \mathrm{Ts}$ ratio. ${ }^{17}$ The above assays were performed on a subsample of our experimental and control groups.

\section{Lymphocyte mitogen activation}

Lymphocyte blastogenic response assays were performed on all subjects. Lymphocytes were cultured in RPMI 1640 with $20 \%$ fetal calf serum (Reheis), penicillin, and streptomycin. One hundred thousand cells per well were distributed in microtitre plates and phytohaemagglutinin (PHA) and pokeweed mitogen (PWM) were added in different doses (PHA in three doses $0.5,1.0$, and $2.0 \mathrm{mg} \%$ and PWM in two doses 0.25 and $0.5 \mathrm{mg} \%$ ). Cultures were incubated at $37^{\circ} \mathrm{C}$ for 72 hours in a humidified $5 \% \mathrm{CO}_{2}$ atmosphere. Labelled ${ }^{3} \mathrm{H}$ thymidine was added and the cells were harvested and counted using a liquid scintillation counter. $^{18}$

\section{Quantitative immunoglobulins}

IgG, IgA, and IgM levels were determined using a rate nephelometric assay system developed by Beckman.

\section{DATA ANALYSIS}

Analyses of the data consisted mainly of characterising the distributions of the various blood assays. We evaluated the mean, median, mode, standard devia- 
tion, and minimum and maximum values of the blood measures periodically as a check on coding, programming, and laboratory procedures.

Statistical analysis was performed using the BMDP statistical software. Standard statistical methods (chisquared tests for contingency tables, $t$ tests, and analysis of variance) were used. Two way analysis of variance was performed on each of the immunological markers with classification of subjects by test groups, smoking status, and asbestos exposure measurements.

\section{Results}

Table 1 shows the descriptive measures for the experimental and control groups from the shipyard. The mean age and the age at first exposure to asbestos were similar for the experimental and control groups.
There was, however, a significant difference between the experimental and control groups in the duration of exposure to asbestos, $25 \cdot 1$ and $21 \cdot 4$ years respectively and in the duration of employment, with a shorter duration of employment in the experimental group than the control group, 14.3 and 17.0 years respectively. The asbestos exposure index was significantly higher in the experimental group than in the control group, 24.5 and 9.5 respectively. A summary of the results of smoking history shows that the frequency of current and former smokers in both the experimental and control groups was similar. The mean pack years smoked in the experimental group was also similar to that in the control group, 20.9 versus 19.4 .

Table 2 gives a summary of the immunological and other blood test results in the experimental and control groups from the shipyard and the tests of comparison

Table 1 Descriptive measures of asbestos exposure and cigarette smoking in shipyard experimental and control groups

\begin{tabular}{|c|c|c|c|c|c|c|c|}
\hline & \multicolumn{3}{|c|}{ Experimental group } & \multicolumn{3}{|c|}{ Control group } & \multirow{2}{*}{$\begin{array}{l}\text { Statistical } \\
\text { test } \\
p \text { value }\end{array}$} \\
\hline & Mean & $S D$ & No & Mean & $S D$ & No & \\
\hline $\begin{array}{l}\text { Age at time of study }(y) \\
\text { Age at first asbestos exposure (y) } \\
\text { Duration of asbestos exposure (y) } \\
\text { Duration of employment at shipyard (y) } \\
\text { Asbestos exposure index } \\
\text { Cigarette smoking (pack-years) }\end{array}$ & $\begin{array}{l}53 \cdot 1 \\
25 \cdot 4 \\
25 \cdot 1 \\
14 \cdot 3 \\
24 \cdot 5 \\
20 \cdot 9\end{array}$ & $\begin{array}{r}7 \cdot 8 \\
9 \cdot 1 \\
10 \cdot 2 \\
6 \cdot 7 \\
19 \cdot 7 \\
22 \cdot 9\end{array}$ & $\begin{array}{l}151 \\
150 \\
150 \\
151 \\
151 \\
145\end{array}$ & $\begin{array}{r}51 \cdot 6 \\
26 \cdot 5 \\
21 \cdot 4 \\
17 \cdot 0 \\
9 \cdot 5 \\
19 \cdot 4\end{array}$ & $\begin{array}{r}7 \cdot 4 \\
8 \cdot 6 \\
10 \cdot 0 \\
6 \cdot 2 \\
10 \cdot 5 \\
22 \cdot 8\end{array}$ & $\begin{array}{l}150 \\
141 \\
141 \\
150 \\
150 \\
146\end{array}$ & $\begin{array}{l}0.07^{*} \\
0.29 * \\
0.002^{*} \\
0.001^{*} \\
0.001 \dagger \\
0.35 \dagger\end{array}$ \\
\hline $\begin{array}{l}\text { Smoking status: } \\
\text { Current } \\
\text { Former } \\
\text { Never }\end{array}$ & $\begin{array}{l}\text { No } \\
51 \\
63 \\
36\end{array}$ & $\begin{array}{l}\% \\
34 \cdot 0 \\
42 \cdot 0 \\
24 \cdot 0\end{array}$ & & $\begin{array}{l}\text { No } \\
48 \\
55 \\
47\end{array}$ & $\begin{array}{l}\% \\
32 \cdot 0 \\
36 \cdot 7 \\
31 \cdot 3\end{array}$ & & \\
\hline
\end{tabular}

${ }^{*} t$ Test comparison of data in original units.

+Wilcoxon rank sum test.

Table 2 Immunological and other blood test results in shipyard experimental and control groups

\begin{tabular}{|c|c|c|c|c|c|c|c|}
\hline \multirow[b]{2}{*}{ Laboratory test } & \multicolumn{3}{|c|}{ Experimental group } & \multicolumn{3}{|c|}{ Control group } & \multirow{2}{*}{$\begin{array}{l}\text { Statistical } \\
\text { test } \\
p \text { value }\end{array}$} \\
\hline & $\overline{N o}$ & $\bar{X}$ & $S D$ & $\overline{N o}$ & $\bar{X}$ & $S D$ & \\
\hline $\begin{array}{l}\text { Mitogen activation (DPM): } \\
\text { PWM } 0.25 \mathrm{mg} / 100 \mathrm{ml} \\
\text { PWM } 0.5 \mathrm{mg} / 100 \mathrm{ml} \\
\text { PHA } 0.5 \mathrm{mg} / 100 \mathrm{ml} \\
\text { PHA } 1.0 \mathrm{mg} / 100 \mathrm{ml} \\
\text { PHA } 2.0 \mathrm{mg} / 100 \mathrm{ml}\end{array}$ & $\begin{array}{l}147 \\
146 \\
147 \\
147 \\
147\end{array}$ & $\begin{array}{r}7037 \\
7366 \\
24399 \\
28217 \\
30277\end{array}$ & $\begin{array}{r}6329 \\
6417 \\
13989 \\
15813 \\
17426\end{array}$ & $\begin{array}{l}147 \\
146 \\
147 \\
147 \\
147\end{array}$ & $\begin{array}{r}5123 \\
5542 \\
21341 \\
24024 \\
26404\end{array}$ & $\begin{array}{l}4502 \\
4550 \\
7358 \\
8291 \\
8836\end{array}$ & $\begin{array}{l}0.001 \dagger \\
0.003 \dagger \\
0.26 \dagger \\
0.09 \dagger \\
0.19 \dagger\end{array}$ \\
\hline $\begin{array}{l}\text { Immunoglobulins }(\mathrm{mg} / 100 \mathrm{ml}) \text { : } \\
\text { IgA } \\
\text { IgG } \\
\text { IgM }\end{array}$ & $\begin{array}{l}136 \\
135 \\
136\end{array}$ & $\begin{array}{r}271 \\
1210 \\
143\end{array}$ & $\begin{array}{r}109 \\
317 \\
70\end{array}$ & $\begin{array}{l}142 \\
143 \\
143\end{array}$ & $\begin{array}{r}258 \\
1187 \\
139\end{array}$ & $\begin{array}{r}112 \\
300 \\
83\end{array}$ & $\begin{array}{l}0 \cdot 34^{*} \\
0 \cdot 54^{*} \\
0.62 \dagger\end{array}$ \\
\hline
\end{tabular}

* $t$ Test comparison of data in original units.

+Wilcoxon rank sum test. 
Table 3 Comparison of the $T$ helper and $T$ suppressor cells between shipyard groups and Red Cross normal controls

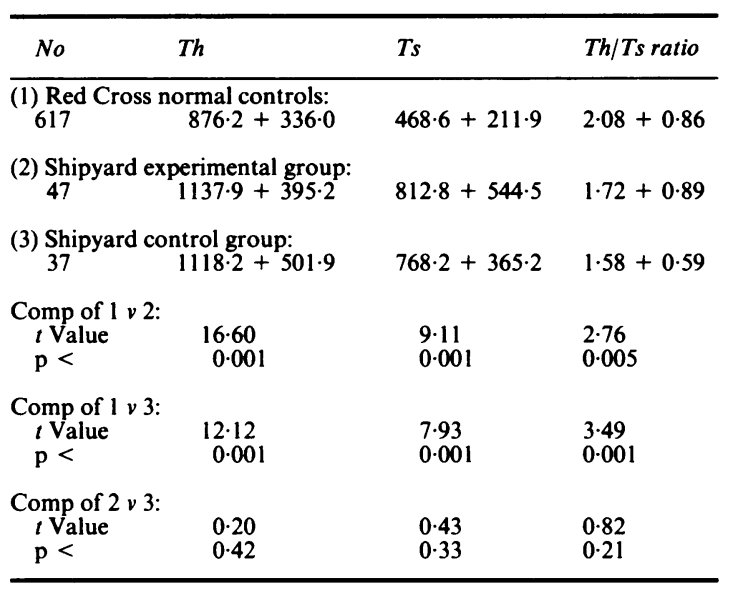

between them. There was no significant difference between the mean white cell counts, total lymphocytes, lymphocyte subpopulations, monocytes, band cells, and segmented cells between the experimental and control groups. The difference in number of eosinophils, however, was statistically significant.

Humoral immune measurements, $\operatorname{IgA}, \operatorname{IgM}$, and $\mathrm{IgG}$, are also presented in table 2 . No difference was observed between the means of the experimental and control groups.

The results for mitogen activation show a significantly higher mean pokeweed mitogen stimulation at both concentrations of mitogen in the experimental group compared with the control group (p $<0.001$ and $<0.003$ ). Although the experimental group had a higher mean stimulation, the differences in mean PHA mitogen stimulation were not significant at the three doses of PHA.

There were no significant differences between the experimental and control groups in the mean number of Th and Ts cells or the Th/Ts cell ratio. As shown in table 3, however, shipyard experimental and control subjects had 1.3 times more Th cells than the Red Cross controls. This excess was significant at $\mathrm{p}<$
0.001 . Similar results were obtained for Ts cells ( $p<$ 0.001 ) when shipyard workers had about 1.7 times as many suppressor cells as the Red Cross controls. On the other hand, Th/Ts ratio was significantly lower in shipyard workers compared with Red Cross controls $(p<0.005)$. There were no significant differences in the levels of Th cells, Ts cells, or Th/Ts between the experimental and control shipyard workers. The subsamples of experimental and control subjects on which immunofluorescent measurement of lymphocyte subsets were performed had similar levels of asbestos exposure as measured by the asbestos index when compared with the experimental and control samples.

\section{Discussion}

Our findings indicate that changes in both cellular and humoral immune responses are associated with asbestos exposure and with the tissue changes diagnosed by chest $x$ ray films as consistent with asbestos exposure. Cellular immune responses, as measured by $\mathrm{T}$ and $\mathrm{B}$ cell mitogen stimulation are affected, confirming the findings of Hartmann ${ }^{15}$ and Wagner. ${ }^{19}$

Pokeweed mitogen stimulation was significantly raised in the experimental group. This indicates that Bcells are responsive to asbestos exposure in agreement with previous results reported for in vitro experiments, ${ }^{20}$ the animal model, ${ }^{21}$ and in man. ${ }^{14} 192223$ Two way analyses of variance were performed to assess the effects of chest $x$ ray findings and the effects of age, smoking, and the asbestos exposure index as well as their possible interaction on mitogen activation. Differences in pokeweed induced mitogen stimulation (table 2) were confirmed for chest $x$ ray abnormality after correction for the effects of age, smoking, and exposure to asbestos. Because of the skewed distributions in the levels of mitogen stimulation, data were transformed by logarithms; similar results were obtained when analyses of variance were performed on the transformed data. We are unaware of these findings having been reported previously.

With regard to humoral immune response, we found no difference in IgM levels between shipyard workers (with or without asbestos stigmata) and Red Cross normal blood donors (table 4). This observation

Table 4 Comparison of shipyard worker group immunoglobulins with those of Red Cross normal controls

\begin{tabular}{|c|c|c|c|c|c|c|c|c|c|}
\hline & \multicolumn{3}{|l|}{$\operatorname{Ig} A$} & \multicolumn{3}{|l|}{$\operatorname{Ig} M$} & \multicolumn{3}{|l|}{$\operatorname{Ig} G$} \\
\hline & No & Mean & $S D$ & No & Mean & $S D$ & No & Mean & $S D$ \\
\hline $\begin{array}{l}\text { (1) Population controls } \\
\text { (2) Shipyard experimentals } \\
\text { (3) Shipyard controls }\end{array}$ & $\begin{array}{l}573 \\
136 \\
142\end{array}$ & $\begin{array}{l}228 \\
271 \\
258\end{array}$ & $\begin{array}{l}105 \\
109 \\
112\end{array}$ & $\begin{array}{l}574 \\
136 \\
143\end{array}$ & $\begin{array}{l}143 \\
143 \\
139\end{array}$ & $\begin{array}{r}112 \\
70 \\
83\end{array}$ & $\begin{array}{l}572 \\
135 \\
143\end{array}$ & $\begin{array}{l}1081 \\
1210 \\
1187\end{array}$ & $\begin{array}{l}268 \\
317 \\
300\end{array}$ \\
\hline $\begin{array}{l}\text { (1) } v(2) \\
\text { (1) } v(3) \\
\text { (2) } v(3)\end{array}$ & $\begin{array}{l}\mathrm{t}=4 \cdot 26 \\
\mathrm{t}=3.01 \\
\mathrm{t}=0.98\end{array}$ & $\begin{array}{l}\mathrm{p}<0.001 \\
\mathrm{p}<0.01 \\
\mathrm{p}<0.17\end{array}$ & & $\begin{array}{l}\mathrm{t}=0.00 \\
\mathrm{t}=0.40 \\
\mathrm{t}=0.43\end{array}$ & $\begin{array}{l}\mathrm{p}<1.00 \\
\mathrm{p}<0.70 \\
\mathrm{p}<0.34\end{array}$ & & $\begin{array}{l}t=4.85 \\
t=4 \cdot 13 \\
t=0.62\end{array}$ & $\begin{array}{l}\mathrm{p}<0.001 \\
\mathrm{p}<0.001 \\
\mathrm{p}<0.27\end{array}$ & \\
\hline
\end{tabular}


is consistent with the fact that the IgM mediated primary humoral response subsides with continuing exposure to an antigen. Our finding that both shipyard groups had significantly higher levels of IgG than the Red Cross controls (table 4) is, however, consistent with the idea that asbestos behaves in the body as a persisting antigen. Immunoglobulin $\mathrm{A}$ was also found to be higher in shipyard workers than in the Red Cross controls. The immunoglobulin levels in shipyard experimental subjects were similar to those in shipyard control subjects. Of interest here is the observation of Huuskonen et al that patients with asbestosis have higher IgA values than controls. ${ }^{14}$ They concluded that the increase in humoral immune response could be used for the evaluation of patients with pulmonary fibrosis.

When we looked at Th and Ts cells, both types were present in significantly greater numbers in the two shipyard groups compared with the Red Cross blood donors, the Ts excess being considerably greater than the Th excess (table 3 ). The greater excess of Ts cells results in $\mathrm{Th} / \mathrm{Ts}$ mean ratios that are smaller than those found in the Red Cross controls, a condition also found in immunodeficient people. Our findings are similar to those of Lew et al who found raised Ts but not raised Th cells in workers exposed to asbestos. ${ }^{22}$

Although statistically significant differences were found when comparisons were made in several of the laboratory tests, their biological importance remain to be determined. It is also recognised that many comparisons were made and that differences can occur as random events and not the result of real effects. Study hypotheses were selected before inspection of the data, and thus results are not selectively reported.

In conclusion, our observations of the humoral immune response as measured by changes in IgG and IgA, the cellular immune response as measured by mitogen stimulation and the disproportionate increase in Ts cells and decrease in Th/Ts cell ratios may, one day, serve as clues to the early diagnosis of susceptibility for asbestos caused malignancy. The test to these clues will depend on a prospective study.

We thank the Office of Naval Research for their support and funding under contract No N00014-80-C0571; Lorraine Wrazen, Corinne Aragaki, and Lee Burke for their help in coding, computerisation, and data analysis; Dr Nicholas Sargent, LAC/USC Medical Center, Los Angeles, for reading the chest $x$ ray films; Cynthia Laudon and Paula Sweet for their help and cooperation with the study team; and Frieda van Schijndel for secretarial help in preparing the manuscript.

\section{References}

1 Copes R, Thomas D, Becklake MR. Temporal patterns of exposure and nonmalignant pulmonary abnormality in Quebec chrysotile workers. Arch Environ Health 1985;40:80-7.

2 Finkelstein MM. A study of dose-response relations for asbestos associated disease. Br J Ind Med 1985;42:319-25.

3 Acheson ED, Gardner MJ, Winter PD, Bennett C. Cancer in a factory using amosite asbestos. Int J Epidemiol 1984;13:3-10.

4 Liddell FDK, Thomas DC, Gibbs GW, McDonald JC. Fibre exposure and mortality from pneumoconiosis, respiratory and abdominal malignancies in chrysotile production in Quebec, 1926-75. Annals of the Academy of Medicine 1984;13:340-4.

5 Rossiter CE, Harries PG. UK naval dockyards asbestos study: survey of the sample population aged 50-59 years. Br J Ind Med 1979;36:281-91.

6 Hilt B, Langard S, Andersen A, Rosenberg J. Asbestos exposure, smoking habits, and cancer incidence among production and maintenance workers in an electrochemical plant. Am J Ind Med 1985;8:565-77.

7 Oliver LC, Eisen EA, Greene RE, Sprince NL. Asbestos-related disease in railroad workers. Am Rev Respir Dis 1985;131: 499-504.

8 Kubota M, Kagamimori S, Yokoyama K, Okada A. Reduced killer cell activity of lymphocytes from patients with asbestosis. Br J Ind Med 1985;42:276-80.

9 Lemaire I, Dubois C, Grondin C, Gingras D. Immunoregulation of lung fibroblast growth: alteration in asbestos-induced pulmonary fibrosis. Clin Exp Immunol 1986;66:201-8.

10 Kagan E, Jacobson RJ, Yeung K-Y, Haidak DJ, Nachnani GH. Asbestos-associated neoplasms of B cell lineage. Am J Med 1979;67:325-30.

11 Gellert AR, Macy MG, Uthayakumar S, Newland AC, Rudd RM. Lymphocyte subpopulations in bronchoalveolar lavage fluid in asbestos workers. Am Rev Respir Dis 1985;132:824-8.

12 Doll NJ, Bozelka BE, Goldbah S, Anorve-Lopez E, Salvaggio JE. Asbestos-induced alteration of human peripheral blood monocyte activity. Int Arch Allergy Appl Immunol 1982;69: $302-5$.

13 Ginns LC, Ryu JH, Rogol PR, Sprince NL, Oliver LC, Larsson CJ. Natural killer cell activity in cigarette smokers and asbestos workers. Am Rev Respir Dis 1985;131:831-4.

14 Huuskonen MS, Rasanen JA, Harkonen H, Asp S. Asbestos exposure as a cause of immunological stimulation. Scandinavian Journal of Respiratory Disease 1978;59:326-32.

15 Hartmann DP. Immunological consequences of asbestos exposure. Survey of Immunological Research 1985;4:65-8.

16 Warheit DB, George G, Hill LH, Snyderman R, Brody AR. Inhaled asbestos activates a complement-dependent chemoattractant for macrophages. Lab Invest 1985;52:505-14.

17 Fahey JL, Prince H, Weaver M, et al. Quantitative changes in T helper or $\mathrm{T}$ suppressor/cytotoxic lymphocyte subsets that distinguish acquired immune deficiency syndrome from other immune subset disorders. Am J Med 1984;76:95-100.

18 Schwab R, Staiano-Coico L, Weksler ME. Immunological studies of aging. IX. Quantitative differences in T lymphocyte subsets in young and old individuals. Diagn Immunol 1983;1:195-8.

19 Wagner MF, Brown DG, Campbell MJ, Coles RM, Edwards RE, Scott MP. Immunological monitoring of an asbestos-exposed population. Arch Immunol Ther Exp (Warsz) 1982;30:201-5.

20 Ueki A, Oka T, Mochizuki Y. Proliferation stimulating effects of chrysotile and crocidolite asbestos fibres on B lymphocyte cell lines. Clin Exp Immunol 1984:56:425-30.

21 Rola-Pleszczynski M, Gouin S. Begin R. Pulmonary and systemic immunoregulatory changes during the development of experimental asbestosis. Clin Exp Immunol 1984;58:325-34.

22 Lew F, Tsang P, Holland JF, Warner N, Selikoff IJ, Bekesi JG. High frequency of immune dysfunctions in asbestos workers and in patients with malignant mesothelioma. J Clin Immunol 1986;6:225-33.

23 Kagan E, Jacobson RJ. Asbestos exposure, immune stimulation and lymphoid malignancy. Advances in Pathology 1982:2: 549-53. 